\title{
Human $\mathrm{Fc}_{\gamma} \mathrm{RII}$, in the Absence of Other $\mathrm{Fc}_{\gamma}$ Receptors, Mediates a Phagocytic Signal
}

Zena Indik, Cathal Kelly, Paul Chien, Arnold I. Levinson, and Alan D. Schreiber

University of Pennsylvania School of Medicine, Philadelphia, Pennsylvania 19104

\begin{abstract}
$\mathrm{Fc}_{\gamma}$ receptors are important components in the binding and phagocytosis of IgG-sensitized cells. Studies on the role of these receptors have been limited by the fact that most hematopoietic cells express more than one $\mathrm{Fc}_{\gamma}$ receptor. We studied the role of $\mathrm{Fc}_{\boldsymbol{\gamma}} \mathrm{RIIA}$ in isolation on a human erythroleukemia cell line (HEL) which expresses $F c_{\gamma}$ RIIA as its only $\mathrm{Fc}_{\boldsymbol{\gamma}}$ receptor. HEL cells were observed to bind and phagocytose IgG-sensitized red blood cells (RBCs) in a dose-dependent manner. We then examined the role of $F c_{\gamma} R I$ and $F c_{\gamma} R I I$ in isolation and in combination, in transfected COS- 1 cells. Fc ${ }_{\gamma}$ RIIA-transfected COS cells also mediated both the binding and phagocytosis of IgG-sensitized RBCs. In contrast, phagocytosis was not observed in $\mathrm{Fc}_{\boldsymbol{\gamma}} \mathrm{RI}$-transfected cells, although these cells avidly bound IgG-sensitized RBCs. Furthermore, coexpression of both receptors by doubly transfected cells did not affect the phagocytic efficiency of $\mathbf{F c}_{\boldsymbol{\gamma}}$ RIIA. These studies establish that Fc $c_{\gamma}$ RIIA can mediate phagocytosis and suggest that transfected COS-1 cells provide a model for examining this process. Since HEL cells exhibit characteristics of cells of the megakaryocyte-platelet lineage, including expression of $\mathrm{Fc}_{\gamma} \mathrm{RII}$ as the only $F c_{\gamma}$ receptor, $F c_{\gamma}$ RIIA on megakaryocytes and platelets may be involved in the ingestion of IgG-containing immune complexes. Furthermore, these studies indicate that $\mathrm{Fc}_{\boldsymbol{\gamma}} \mathbf{R I}$ and Fc $\mathbf{r}_{\boldsymbol{\gamma}}$ RIIA differ in their requirements for transduction of a phagocytic signal. (J. Clin. Invest. 1991. 88:1766-1771.) Key words: receptors • platelets • phagocytosis • immunoglobulin
\end{abstract}

\section{Introduction}

Hematopoietic cells express a wide range of surface molecules including those of the $\mathrm{Fc}_{\gamma}$ receptor family (1-3). These receptors are important in host defense because they represent a major mechanism for the detection and phagocytosis of such antibody- (IgG) sensitized cells as microorganisms. Six distinct genes which encode $\mathrm{Fc}_{\gamma}$ receptor proteins have been cloned. These have been classified as $\mathrm{Fc}_{\gamma} \mathrm{RI}, \mathrm{Fc}_{\gamma} \mathrm{RII}(\mathrm{A}, \mathrm{B}$, and $\mathrm{C}$ ), and $F_{\gamma} R I I I(A$ and $B)(4-6)$. These receptors are all members of the

Address correspondence to Zena Indik, University of Pennsylvania Cancer Center, 7 Silverstein, 3400 Spruce Street, Philadelphia, PA 19104. 1991.

Received for publication 20 March 1991 and in revised form 24 June

J. Clin. Invest.

(c) The American Society for Clinical Investigation, Inc.

0021-9738/91/11/1766/06 \$2.00

Volume 88, November 1991, 1766-1771
Ig gene superfamily and can be distinguished from each other by size, primary structure, ligand affinity, and MAb reactivity (7-9). Although the extracellular $\mathrm{Fc}_{\boldsymbol{\gamma}}$-binding domains of the three receptors show considerable homology, the differences in the cytoplasmic domains suggest that they transmit different signals and subserve different functions. In this regard, although each of these $\mathrm{Fc}_{\gamma}$ receptor proteins is able to bind IgGcoated cells, the specific $\mathrm{Fc}_{\gamma}$ receptor(s) responsible for phagocytosis is ill-defined.

Most hematopoietic cells, including phagocytic cells such as macrophages and granulocytes, express more than one $\mathrm{Fc}_{\gamma}$ receptor protein (7). Therefore, it has been difficult to define which $\mathrm{Fc}_{\gamma}$ receptor protein(s) is able to transduce a signal in the absence of a cooperative role from another class of $\mathrm{Fc}_{\gamma}$ receptor, using normal cells or cell lines. We used two approaches to address this issue. First, we studied the role of $\mathrm{Fc}_{\gamma} \mathrm{RII}$ in human erythroleukemia (HEL) cells, a leukemic cell line that retains a number of features of the megakaryocyte-platelet lineage (10). Like platelets-megakaryocytes, HEL cells express $\mathrm{Fc}_{\gamma}$ RII, primarily $\mathrm{Fc}_{\gamma}$ RIIA as their only $\mathrm{Fc}_{\gamma}$ receptor class (King, M., P. G. Comber, P. Chien, P. Ruiz, and A. D. Schreiber, manuscript submitted for publication) (11-13). Second, by transfecting $\mathrm{Fc}_{\gamma} \mathrm{RI}$ and $\mathrm{Fc}_{\gamma} \mathrm{RIIA}$ separately and together into COS-1 cells, a fibroblast-derived cell line lacking endogenous $\mathrm{Fc}_{\gamma}$ receptors, we were able to assess the properties of each receptor in a controlled manner. COS-1 cells were selected because of their efficiency of transfection and because of their potential for mediating a phagocytic signal (14). We were able to use these two approaches to determine whether $\mathrm{Fc}_{\gamma}$ RIIA can mediate phagocytosis in isolation and to assess whether dual expression of receptors, in the case of doubly transfected COS- 1 cells, affects individual $\mathrm{Fc}_{\gamma}$ receptor phagocytic function.

\section{Methods}

Cell culture and reagents. COS-1 cells were maintained in DME containing glucose $(4.5 \mathrm{mg} / \mathrm{ml})$, glutamine $(25 \mathrm{mg} / \mathrm{ml})$, penicillin $(100 \mathrm{U} /$ $\mathrm{ml})$, streptomycin $(100 \mu \mathrm{g} / \mathrm{ml})$, and $10 \%$ heat-inactivated FCS. $24 \mathrm{~h}$ before transfection cells were seeded onto $3.5-\mathrm{cm}$ wells at a concentration of $3 \times 10^{5} /$ well, in order for cells to reach $\sim 80 \%$ confluence for transfection.

The HEL cell line was obtained from Dr. Eli Schwartz and Dr. Mortimer Poncz (Children's Hospital of Philadelphia, Philadelphia, PA) and maintained in RPMI 160 medium (Gibco Laboratories, Grand Island, NY) supplemented with glutamine, penicillin, streptomycin, and FCS. Cell passages were performed approximately every 3 $\mathrm{d}$ and the cells were studied in the exponential phase of growth.

Cytochalasin D (Sigma Chemical Co., St. Louis, MO) was dissolved in dimethylsulfoxide and diluted into culture medium to a concentration of $10 \mu \mathrm{g} / \mathrm{ml}$. Both the anti-Fc $\mathrm{c}_{\gamma}$ RII monoclonal antibody IV.3 (7) 
and the anti- $\mathrm{Fc}_{\gamma} \mathrm{RI}$ monoclonal antibody 32.2 (7) were isolated from ascites fluid (kindly provided by Dr. Clark L. Anderson, Ohio State University, Columbus, OH, and Dr. Michael Fanger, Dartmouth Medical School, Hanover, NH) using protein A (Affi-Gel Protein A Maps II, Bio-Rad Laboratories, Richmond, CA). The ascites fluid (1.5 ml) was applied to a 5-ml protein A agarose column. The column was washed with 15 vol of buffer and the IgG eluted with $\mathrm{pH} 2.8$ buffer. The eluted protein was dialyzed against PBS and concentrated to $7 \mathrm{mg} / \mathrm{ml}$.

Transient transfection of COS-1 cells. Transient transfection of COS- 1 cells was carried out in complete media containing $10 \% \mathrm{Nu}$ Serum (Collaborative Research Inc., Waltham, MA) instead of FCS, DEAE-dextran $(400 \mu \mathrm{g} / \mathrm{ml})$, chloroquine chloride $(100 \mu \mathrm{M})$, and $250-$ $500 \mathrm{ng}$ plasmid DNA per $3.5 \mathrm{~cm}$ well. After $4 \mathrm{~h}$ at $37^{\circ} \mathrm{C}$, the transfection media was replaced with $10 \%$ DMSO in PBS for 2 min at room temperature. The cells were then washed and fresh media added for further incubation. Cells were harvested for analysis after $48 \mathrm{~h}$. For these transfection studies we used p135, a plasmid containing fulllength human $\mathrm{Fc}_{\gamma} \mathrm{RI}$ cDNA in CDM8, a vector utilizing the CMV promoter (15); and $\mathrm{HFc} 3.0$, a plasmid containing full-length human $\mathrm{Fc}_{\gamma} \mathrm{RIIA}$ in the SV40-based pKC4 vector (16). p135 was the gift of Dr. Brian Seed (Massachusetts General Hospital, Boston, MA) and HFc 3.0 was the gift of Dr. P. Mark Hogarth (University of Melbourne, Melbourne, Australia).

Flow cytometry. Monoclonal antibodies directed against $\mathrm{Fc}_{r} \mathrm{RII}$ (MAb IV.3) and $\mathrm{Fc}_{\gamma} \mathrm{RI}$ (MAb 32.2) (7) were used to assess receptor protein expression in transfected COS-1 cells. Cell samples were incubated at $4^{\circ} \mathrm{C}$ with fluorescein-labeled MAb IV.3 and/or biotin-conjugated MAb 32.2. Biotin conjugates were stained with streptavidin-phycoerythrin. Isotype controls were employed for all reactions. Stained cells were fixed with $4 \%$ paraformaldehyde until analysis by flow cytometry. Fluorescence was measured on a FACStar (Becton-Dickinson, Mountainview, CA). For all samples 10,000 events were recorded on a logarithmetic fluorescence scale and mean fluorescence intensity data and contour maps generated using Consort 30 software. Anti- $\mathrm{Fc}_{\gamma} \mathrm{RI}$ and anti-Fc $\mathrm{C}_{\gamma} \mathrm{RII}$ MAbs were employed following standardization with U-937 cells expressing a known quantity of $\mathrm{Fc}_{\gamma} \mathrm{RI}$ and $\mathrm{Fc}_{\gamma} \mathrm{RII}$. U-937 expressed approximately 20,000-30,000 $\mathrm{Fc}_{\gamma} \mathrm{RI}$ and 30,000-50,000 $\mathrm{Fc}_{\gamma} \mathrm{RII}(17,18)$. U-937 cells stained with our streptavidin-phycoerythrin-biotin-anti- $\mathrm{Fc}_{\gamma} \mathrm{RI}$ have a shift of 208 mean fluorescent intensity (MFI) units compared to an isotype control and a shift of $110 \mathrm{MFI}$ units when stained with our FITC-anti-Fc ${ }_{\gamma}$ RII.

Preparation of IgG-sensitized red blood cells. Sheep red blood cells (RBCs) were sensitized with rabbit IgG anti-sheep RBC antibody as previously described (19). In brief, for most experiments $10^{9}$ sheep $\mathrm{RBCs} / \mathrm{ml}$ (sterile sheep red blood cells; Rockland Inc., Gilbertsville, PA) in calcium and magnesium-free PBS/(PBS-) were sensitized by incubation with an equal volume of the highest subagglutinating concentration of rabbit anti-sheep RBC antibody (Cappel Laboratories, Cochranville, $\mathrm{PA}$ ) at $37^{\circ} \mathrm{C}$ for $1 \mathrm{~h}$. The IgG-sensitized sheep RBCs were washed twice, resuspended in PBS $^{-}$to a final concentration of $10^{9}$ $\mathrm{RBCs} / \mathrm{ml}$ and overlaid on transfected COS- 1 cell or HEL cell monolayers.

Binding and phagocytosis of IgG-sensitized RBCs. Prior to each experiment HEL cells were harvested by sedimentation at $180 \mathrm{~g}$ and then washed three times with $\mathrm{PBS}^{=} .10^{6}$ cells were incubated with IgGsensitized RBCs (EA) at $37^{\circ} \mathrm{C}$ and examined by light microscopy. Binding and phagocytosis of EA by COS-1 cells and HEL cells were evaluated with RBCs sensitized with antibody dilutions from 1:250 through $1: 8,000$, as previously described (19). COS-1 or HEL cells were incubated with washed EA at $37^{\circ} \mathrm{C}$ for $30 \mathrm{~min}$. The unbound EA were removed by washing and the plates were stained with Wright-Giemsa. At least 300 COS-1 or HEL cells were examined by light microscopy and those cells binding five or more (EA) tallied in a blinded fashion. To assess phagocytosis, parallel groups of cells were briefly exposed to a hypotonic solution to remove adherent EA. The cells were then stained with Wright-Giemsa and the number of COS-1 or HEL cells with internalized EA were determined in a blinded fashion. Results were analyzed statistically by Student's $t$ test.

\section{Results}

Binding of IgG-sensitized red blood cells by HEL cells. HEL cells, which express $\mathrm{Fc}_{\gamma} \mathrm{RII}$ as their only $\mathrm{Fc}_{\gamma}$ receptor (King et al., submitted for publication), bound IgG-sensitized RBCs in a dose-dependant manner (Figs. 1 and $2 A$ ). At 1:250 and 1:2,000 dilutions of antibody, 83 and $58 \%$ of HEL cells bound EA, respectively. Similar results were observed at 30,60 , and 120 min incubation of HEL cells with EA. Furthermore, the interaction was inhibited by anti-Fc ${ }_{\gamma}$ RII antibody $(P<0.001)$ (Fig. 1).

Expression of $F c_{\gamma}$ receptors in transfected COS-1 cells. $48 \mathrm{~h}$ after transfection of COS- 1 cells, cell surface-receptor expression was determined by FACS ${ }^{\circledR}$ analysis using biotin-conjugated anti-Fc ${ }_{\gamma} \mathrm{RI}$ and/or fluoroscein-labeled anti-Fc $\mathrm{c}_{\gamma} \mathrm{RII}$. A fluorescence histogram of $\mathrm{Fc}_{\gamma} \mathrm{RI}$ and $\mathrm{Fc}_{\gamma} \mathrm{RII}$ individual transfectants is shown in Fig. 3. Both receptors were efficiently expressed in transfected COS-1 cells (MFI $=547$ for $\mathrm{Fc}_{\gamma} \mathrm{RI}$ transfectants and 266 for $\mathrm{Fc}_{\gamma}$ RIIA transfectants, a relative difference similar to that observed for the expression of these receptors on U-937 cells). In the experiment shown in Fig. 4, $\sim 48 \%$ of the $\mathrm{Fc}_{\gamma}$ RI- (Fig. $4 \mathrm{~A}$ ) and $40 \%$ of the $\mathrm{Fc}_{\gamma}$ RII- (Fig. 4 $B)$ transfected cells expressed receptor protein. In cell populations transfected with both $\mathrm{Fc}_{\gamma} \mathrm{RI}$ and $\mathrm{Fc}_{\gamma} \mathrm{RIIA}, 34 \%$ of the cells expressed both receptorsi(Fig. $4 C$ ).

Binding of IgG-sensitized red blood cells by transfected COS-1 cells. At high concentrations of IgG/RBC, COS- 1 cells expressing transfected $\mathrm{Fc}_{\gamma} \mathrm{RIIA}$ and/or $\mathrm{Fc}_{\gamma} \mathrm{RI}$ avidly bound opsonized sheep RBCs (Figs. $2 C$ and 5). There were no differences in binding capacity among different cell populations incubated with $\mathrm{EA}$ for 30,60 , or $120 \mathrm{~min}$. We routinely observed that $35-48 \%$ of transfected cells bound EA (Fig. 5) and that most of these cells bound $>20 \mathrm{EA} /$ cell. No binding was observed in mock transfected cells. With decreasing concentrations of IgG/RBC, the EA-binding capacity of Fc ${ }_{\gamma}$ RIIA-transfected COS- 1 cells fell rapidly. $40 \%$ of these transfected COS- 1 cells bound EA at a 1:250 dilution of antibody and $11 \%$ bound EA at an antibody dilution of $1: 1,000$. In contrast, a high percentage of $F c_{\gamma} R I$-transfected cells retained the capacity to bind large numbers of EA even at very low concentrations of IgG/ RBC (e.g., 30\% of COS-1 cells bound EA at a 1:4,000 antibody dilution). Cell populations doubly transfected with $\mathrm{Fc}_{\gamma} \mathrm{RI}$ and $\mathrm{Fc}_{\gamma} \mathrm{RIIA}$ were similar to $\mathrm{Fc}_{\gamma} \mathrm{RI}$-transfected cells in that they

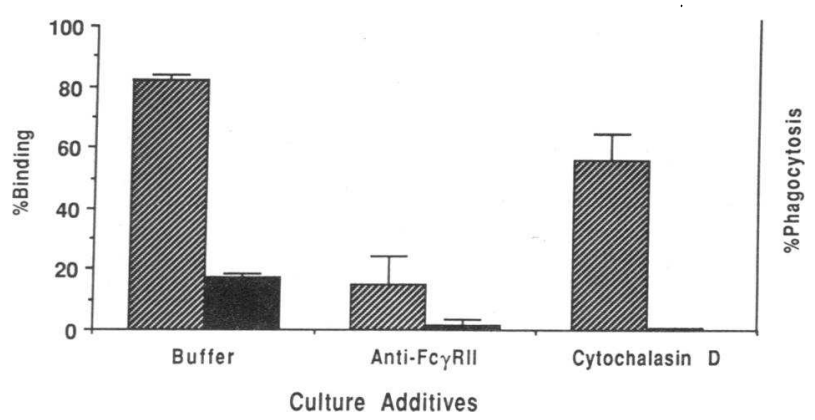

Figure 1. Binding and phagocytosis of IgG-sensitized RBCs (EA) by HEL cells. The solid rectangles represent phagocytosis of EA and the hatched rectangles binding of EA by HEL cells. The mean of \pm SD of three to four experiments is shown with RBCs sensitized with 1:500 dilutions of anti-RBC antibody. 

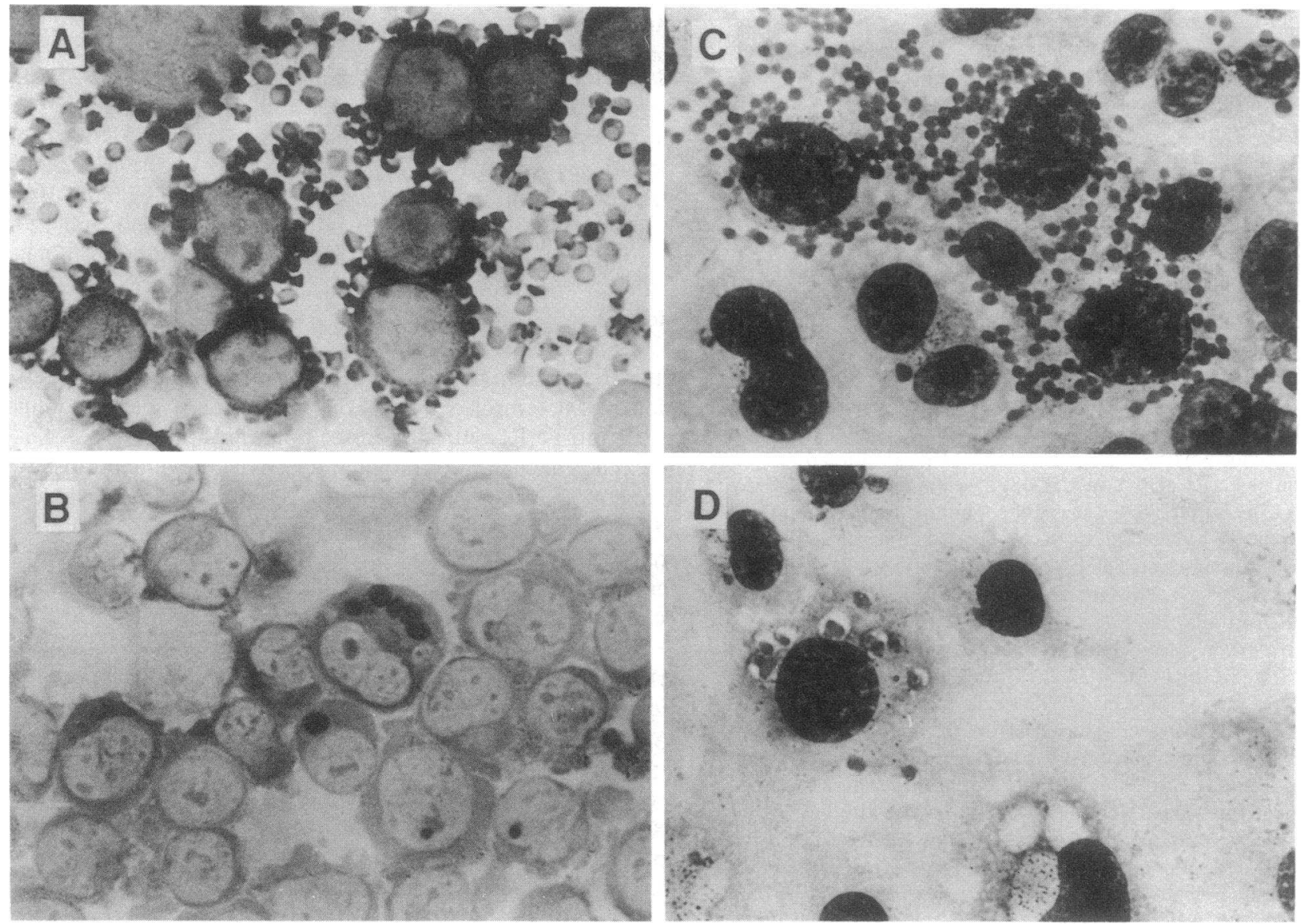

Figure 2. Binding and phagocytosis of IgG-sensitized RBCs (EA) by HEL cells and transfected COS-1 cells. $(A)$ Binding of EA by HEL cells. (B)

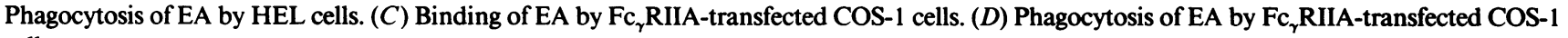
cells.

bound EA relatively efficiently at low concentrations of $\mathrm{IgG/RBC.}$

Phagocytosis of IgG-sensitized red blood cells by transfected COS-1 and HEL cells. COS-1 and HEL cells were incubated at
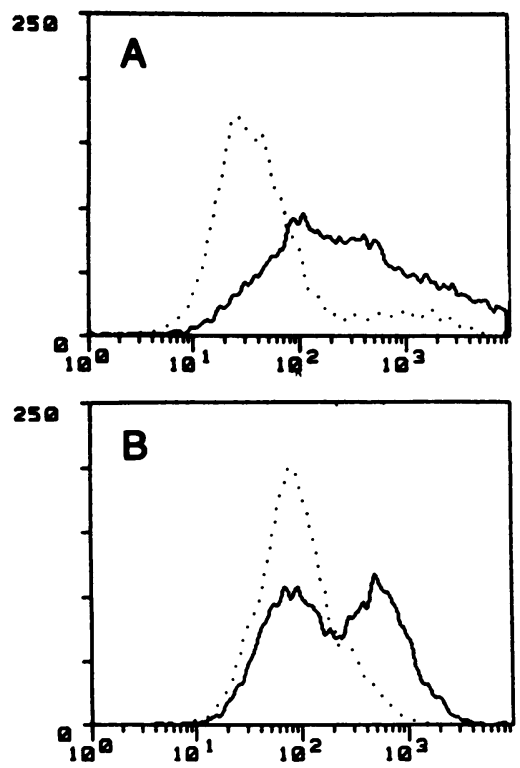

Figure 3. Fluorescence histogram of COS-1 cells transfected with either $\mathrm{Fc}_{\gamma} \mathrm{RI}(A)$ or $\mathrm{Fc}_{\gamma}$ RIIA $(B) . \mathrm{Fc}_{\gamma}$ RI and $\mathrm{Fc}_{\gamma}$ RIIA transfectants were stained with directly conjugated anti$\mathrm{Fc}_{\gamma} \mathrm{RI}$ and anti-Fc $\mathrm{c}_{\gamma} \mathrm{RII}$ respectively. The broken line represents the fluorescence histogram of cells stained with an isotype control MAb.

The solid line represents cells stained with anti$\mathrm{Fc}_{\gamma}$ receptor MAb. $37^{\circ} \mathrm{C}$ with EA and stained with Wright-Giemsa after hypotonic lysis of externally bound EA. 16-19\% of HEL cells phagocytosed EA following 30,60 and 120 min incubation with EA at $37^{\circ} \mathrm{C}$ (Figs. 1 and $2 \mathrm{~B}$ ). The variation in intracellular degradation of EA by HEL cells made accurate assessment of the extent of phagocytosis difficult after prolonged incubation. Therefore, phagocytosis was assessed after $30 \mathrm{~min}$ of HEL cell-EA incubation. Cytochalasin $\mathrm{D}$, a reagent which inhibits actin polymerization, completely abrogated phagocytosis $(P<0.001)$ and preincubation of HEL cells with anti-Fc ${ }_{\gamma}$ RII MAb significantly $(P$ $<0.001$ ) reduced phagocytosis from 17 to $1 \%$ (Fig. 1).

No phagocytosis was observed in $\mathrm{Fc}_{\gamma} \mathrm{RI}$-transfected populations of COS-1 cells even at high concentrations of IgG/RBC after 30,60 , or $120 \mathrm{~min}$ incubations with EA, even though these cells bound large numbers of EA externally. In contrast, at high concentrations of IgG/RBC (1:250 and 1:500 antibody dilutions) phagocytosis of EA proceeded rapidly in cell populations expressing $\mathrm{Fc}_{\gamma}$ RIIA. 12-20\% of $\mathrm{Fc}_{\gamma}$ RIIA-transfected cells contained ingested RBCs after 30 min of incubation with EA at $37^{\circ} \mathrm{C}$ (Figs. 5 and $2 \mathrm{D}$ ). There was a decrease in the number of cells containing ingested RBCs after 1 or $2 \mathrm{~h}$ of incubation with $\mathrm{EA}$, and both empty vacuoles and vacuoles containing partially digested RBCs were observed at that time. There was no evidence of phagocytosis in $\mathrm{Fc}_{\boldsymbol{\gamma}}$ RIIA-transfected cells incubated with EA at $0^{\circ} \mathrm{C}$ for $30 \mathrm{~min}$ or in cells incubated in the presence of cytochalasin D. The ability of $\mathrm{Fc}_{\boldsymbol{\gamma}}$ RIIA-transfected cells to 

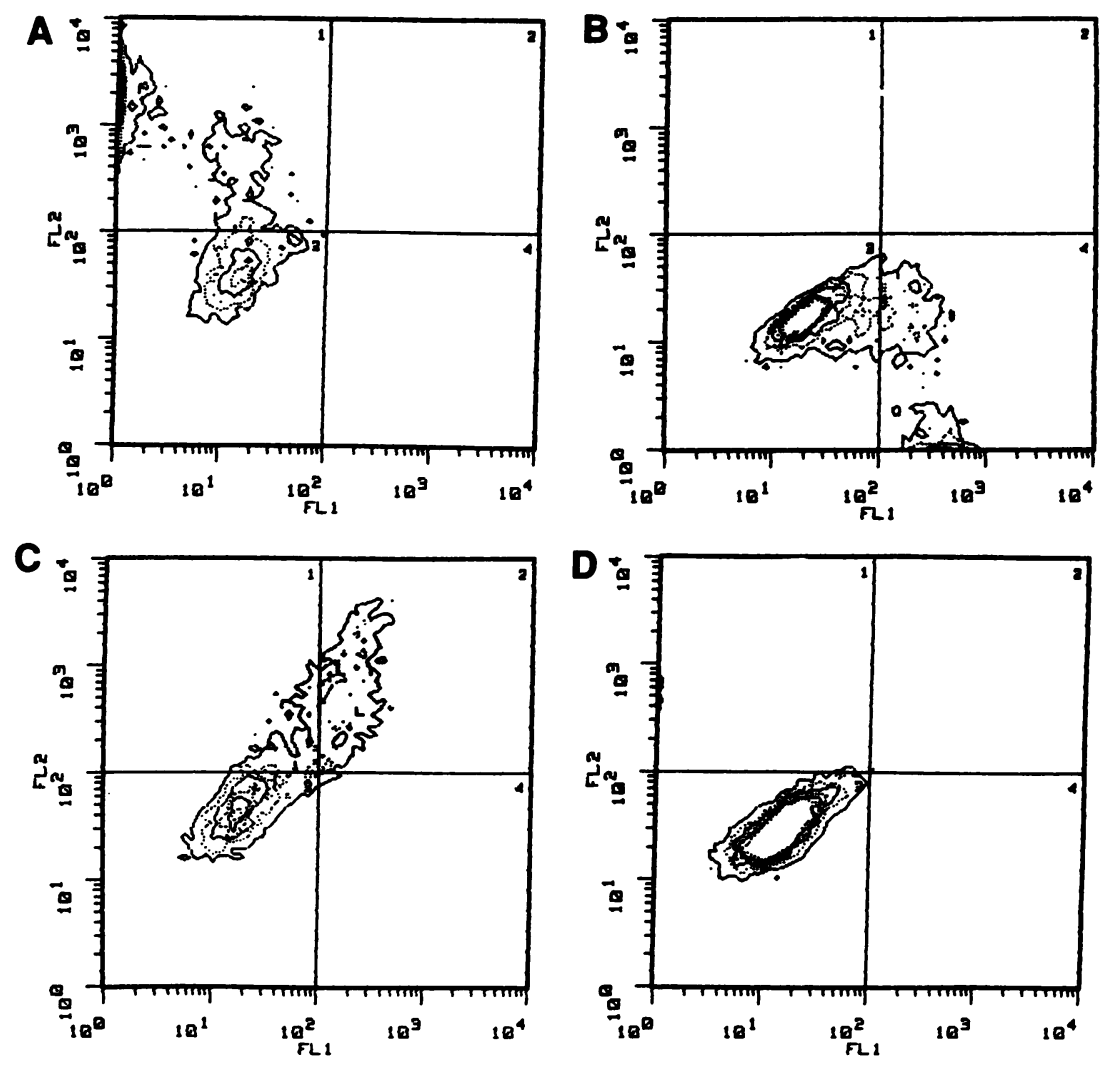

Figure 4. FACS analysis of transfected COS-1 cells. Fc $\mathrm{c}_{\gamma}$ RIIA-transfected COS-1 cells were stained with fluorescein-conjugated anti-Fc ${ }_{\gamma} \mathrm{RII}$. $\mathrm{Fc}_{\gamma} \mathrm{RI}$-transfected cells were incubated with biotin-conjugated anti- $\mathrm{Fc}_{\boldsymbol{r}} \mathrm{RI}$ and stained with streptavidin-phycoerythrin. Doubly transfected cells and sham transfected cells were stained with both MAbs. $(A)$ COS-1 cells transfected with $\mathrm{Fc}_{\gamma} \mathrm{RI}$ cDNA. $(B)$ COS-1 cells transfected with Fc $\mathrm{c}_{\gamma}$ IIIA cDNA. $(C)$ COS-1 cells cotransfected with $\mathrm{Fc}_{\gamma} \mathrm{RI}$ and $\mathrm{Fc}_{\gamma}$ RIIA cDNA. (D) Sham transfected COS-1 cells. phagocytose EA was clearly dependent on IgG concentration. Phagocytosis fell rapidly at antibody dilutions $>1: 500(<1 \%$ of cells internalized EA at $>1: 1,000$ antibody dilutions), paralleling the decreased ability of these cells to bind EA at these antibody concentrations. High concentrations of $\mathrm{IgG} / \mathrm{RBC}$ were also required for phagocytosis of EA in cells doubly transfected with $\mathrm{Fc}_{\boldsymbol{\gamma}} \mathrm{RI}$ and $\mathrm{Fc}_{\boldsymbol{\gamma}} \mathrm{RIIA}$ (9-16\% phagocytic cells). There was no evidence that coexpression of $\mathrm{Fc}_{\gamma} \mathrm{RI}$ mediated an increase in phagocytosis at any IgG antibody concentration.

\section{Discussion}

Since $\mathrm{Fc}_{\gamma}$ receptor-expressing cells such as monocytes, macrophages, and granulocytes express more than one class of $\mathrm{Fc}_{\gamma}$

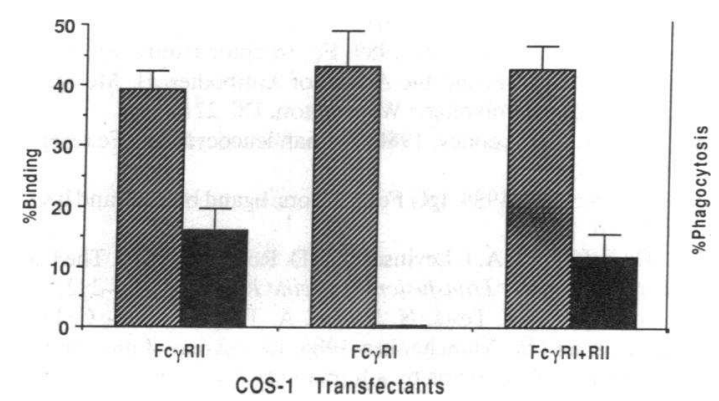

Figure 5. Binding and phagocytosis of IgG-sensitized RBCs (EA) by transfected COS- 1 cells. The solid rectangles represent phagocytosis of EA and the hatched rectangles represent binding of EA by transfected COS-1 cells. The mean \pm SD of three experiments is shown with RBCs sensitized with 1:500 dilutions of anti-RBC antibody. receptor (1-3), it is difficult to assess whether one $\mathrm{Fc}_{\gamma}$ receptor class can mediate a phagocytic signal without the influence of another. Most previous studies have utilized complexes of individual IgG subclasses or specific MAbs as probes for phagocytosis. These reagents do not permit complete discrimination between individual $\mathrm{Fc}_{\gamma}$ receptor classes. For example, the affinity of $\mathrm{Fc}_{\gamma}$ receptors for individual IgG isotypes is relative rather than absolute. Similarly, the affinity of $\mathrm{MAb}$ for $\mathrm{Fc}_{\gamma}$ receptor epitopes may not allow for complete inhibition of IgG ligand binding. In addition, these reagents do not address the possibility of interactions between $\mathrm{Fc}_{\gamma}$ receptors that involve domains other than those in the extracellular region. For example, activation of $\mathrm{Fc}_{\gamma}$ receptors by ligand or antibody binding may result in a signal which involves the transmembrane or cytosolic domain of other $\mathrm{Fc}_{\gamma}$ receptor classes.

To study the role of $\mathrm{Fc}_{\gamma} \mathrm{RII}$ in isolation, we first examined $\mathrm{Fc}_{\gamma}$ receptor function in the human erythroleukemia cell line HEL. This cell line was previously demonstrated to express a number of markers characteristic of cells of the megakaryocyte-platelet lineage including alpha-granule proteins, glycoproteins $\mathrm{Ib}$, IIb/IIIa and the platelet alloantigen $\mathrm{PI}^{\mathrm{AI}}$ (10). In addition, HEL cells under certain conditions were shown to bind IgG-sensitized cells (20), suggesting the presence of $\mathrm{Fc}_{\gamma}$ receptors. In a previous study we used a panel of monoclonal antibodies directed at epitopes specific for each of the three classes of human $\mathrm{Fc}_{\gamma}$ receptors, as well as Northern blot and PCR analysis, to establish that $\mathrm{Fc}_{\gamma} \mathrm{RII}$ (predominantly FC $\gamma$ RIIA) is the only $\mathrm{Fc}_{\gamma}$ receptor expressed by HEL cells (King et al., submitted for publication) $(11,12)$. Thus, this cell line provided a tool for assessing $\mathrm{Fc}_{\gamma}$ RIIA function in a human cell. Our data indicate that $\mathrm{Fc}_{\gamma}$ RIIA mediates both binding and phagocytosis of IgG-sensitized RBCs in the absence of other 
$\mathrm{Fc}_{\gamma}$ receptors. We have also observed that a high affinity $\mathrm{MAb}$ that competes for the $\mathrm{Fc}_{\gamma} \mathrm{RII}$ ligand binding site $(5,7,15)$ inhibits this process (Fig. 1).

We then introduced individual $\mathrm{Fc}_{\gamma}$ receptors by transient transfection into a cell line lacking endogenous $\mathrm{Fc}_{\gamma}$ receptors to establish an approach for studying individual $\mathrm{Fc}_{\gamma}$ receptor function and interaction. Transfection of cDNAs encoding human $\mathrm{Fc}_{\gamma} \mathrm{RI}$ and $\mathrm{Fc}_{\gamma} \mathrm{RIIA}$ into COS- 1 cells was an efficient means of obtaining cells that express individual $\mathrm{Fc}_{\gamma}$ receptors. As measured by FACS analysis, $25-48 \%$ of transfected cell populations expressed these receptors. Thus, we were able to study binding and phagocytosis of IgG-sensitized erythrocytes by $\mathrm{Fc}_{\gamma} \mathrm{RI}$ and $\mathrm{Fc}_{\gamma} \mathrm{RIIA}$, individually and paired, under controlled conditions. Only COS- 1 cells expressing $\mathrm{Fc}_{\gamma}$ RIIA could phagocytose IgG-sensitized erythrocytes. Ingestion by $\mathrm{Fc}_{\gamma}$ RIIA transfectants occurred only with high concentrations of IgG per $\mathrm{RBC}$. In contrast, $\mathrm{Fc}_{\gamma} \mathrm{RI}$ transfectants were unable to mediate phagocytosis at any concentration of IgG per RBC examined. In addition, since no difference in the pattern of efficiency of phagocytosis was observed in doubly-transfected cells, it appears that in COS- 1 cells coexpression of $\mathrm{Fc}_{\gamma} \mathrm{RI}$ and $\mathrm{Fc}_{\gamma} \mathrm{RIIA}$ does not influence the process of phagocytosis by $\mathrm{Fc}_{\gamma}$ RIIA.

The inability of $\mathrm{Fc}_{\gamma} \mathrm{RI}$ on COS-1 cells to mediate a phagocytic signal after binding EA may relate to intrinsic differences in the $\mathrm{Fc}_{\gamma} \mathrm{RI}$ and $\mathrm{Fc}_{\gamma} \mathrm{RIIA}$ receptors. There are data that indicate that both $\mathrm{Fc}_{\gamma} \mathrm{RI}$ and $\mathrm{Fc}_{\gamma} \mathrm{RII}$ on other cells are able to phagocytose EA (21). While COS-1 cells may lack the necessary accessory molecules to allow phagocytosis by $\mathrm{Fc}_{\gamma} \mathrm{RI}$, they possess the elements necessary for $\mathrm{Fc}_{\gamma} \mathrm{RII}$-mediated phagocytosis. Our studies, therefore, suggest that $\mathrm{Fc}_{\gamma} \mathrm{RI}$ and $\mathrm{Fc}_{\gamma} \mathrm{RIIA}$ differ in their requirements for transmission of a phagocytic signal.

Since the isolation of the receptor proteins and their genes (3-9), the functional role of human $\mathrm{Fc}_{\gamma}$ receptors has been the focus of investigation in several cell systems. The data concerning the role of the three human $\mathrm{Fc}_{\gamma}$ receptors is conflicting. There are data using MAbs that show that hematopoietic cells are able to phagocytose ox RBCs by $\mathrm{Fc}_{\gamma} \mathrm{RI}$ and $\mathrm{Fc}_{\gamma} \mathrm{RII}$ (21). However, a similar approach demonstrated that phagocytosis of tumor cells by cultured monocytes was mediated by $\mathrm{Fc}_{\gamma} \mathrm{RII}$ and $\mathrm{Fc}_{\gamma} \mathrm{RIII}$, but not $\mathrm{Fc}_{\gamma} \mathrm{RI}$ (22). Our studies indicate that phagocytosis in a transfected COS- 1 cell is mediated by $\mathrm{Fc}_{\gamma}$ RIIA, but not $\mathrm{Fc}_{\gamma}$ RI.

The importance of $\mathrm{Fc}_{\gamma} \mathrm{RII}$ in phagocytosis, as reported herein, is supported by studies in murine systems. For example, murine $\mathrm{Fc}_{\gamma} \mathrm{RII}$ was observed to play a significant role in immune clearance (23), a process closely related to phagocytosis. Furthermore, phagocytosis of IgG-coated Toxoplasma gondii has been noted to be mediated by transfected murine $\mathrm{Fc}_{\gamma} \mathrm{RII}$ (24). Our studies are consistent with a role for human $\mathrm{Fc}_{\gamma} \mathrm{RII}$ in the clearance of IgG-sensitized cells. Furthermore, because $\mathrm{Fc}_{\gamma} \mathrm{RII}$ is the only $\mathrm{Fc}_{\gamma}$ receptor present on human platelets and the megakaryocyte-like cell line HEL, our studies also suggest that $\mathrm{Fc}_{\gamma}$ RIIA on platelets may play a hitherto unsuspected role in phagocytosis.

A family has been described with a deficiency of monocyte surface $\mathrm{Fc}_{\gamma} \mathrm{RI}$ (25). Because their monocytes were able to mediate phagocytosis of EA that was inhibited by anti-Fc $\mathrm{c}_{\gamma} \mathrm{RII}$, it was suggested that $\mathrm{Fc}_{\gamma} \mathrm{RII}$ can mediate phagocytosis of IgG-sensitized cells in the absence of other $\mathrm{Fc}_{\gamma}$ receptors. However, it is uncertain whether the monocytes of these patients express $\mathrm{Fc}_{\gamma} \mathrm{RI} \mathrm{mRNA}$ and/or low levels of the high affinity $\mathrm{Fc}_{\gamma} \mathrm{RI}$ protein. Furthermore, there are data that indicate that monocytes express low levels of $\mathrm{Fc}_{\gamma} \mathrm{RIII}$ (26), which might contribute to phagocytosis in these patients. Studies in human subjects suggest that $\mathrm{Fc}_{\gamma} \mathrm{RIII}$ is involved in the clearance of IgG-sensitized cells in autoimmune disease $(27,28)$.

We observed that COS-1 cells transfected with $\mathrm{Fc}_{\boldsymbol{\gamma}} \mathrm{RI}$ are able to bind RBCs sensitized with considerably lower concentrations of IgG antibody than COS-1 cells transfected with $\mathrm{Fc}_{\gamma} \mathrm{RIIA}$. This likely reflects the increased affinity of $\mathrm{Fc}_{\gamma} \mathrm{RI}$ for monomeric and complexed $\operatorname{IgG}(5,7,15)$. $\mathrm{Fc}_{\gamma} \mathrm{RI}$ may be occupied by IgG in vivo, whereas $\mathrm{Fc}_{\gamma} \mathrm{RII}$ does not bind this monomeric protein. Because $\mathrm{Fc}_{\gamma}$ RIIA binds monomeric IgG inefficiently, $\mathrm{Fc}_{\gamma} \mathrm{RIIA}$ may have phagocytic function in tissues in vivo.

These studies imply that both COS- 1 cells and HEL cells may serve as models for the study of individual human receptor functions. Our studies also suggest that these cells have potential value for the examination of phagocytic mechanisms. As with phagocytosis in hematopoietic cells, ingestion of RBCs required an intact cytoskeleton, as indicated by sensitivity to cytochalasin D. Furthermore, we observed that both transfected COS- 1 cells and HEL cells were not only able to phagocytose IgG-sensitized cells by $\mathrm{Fc}_{\gamma}$ RIIA, but also appeared able to degrade EA within vacuole-like structures. Thus, COS-1 cells, a cell line derived from monkey kidney fibroblasts, and HEL cells, which have properties common to cells of the megakaryocyte/platelet lineage, may serve as models for understanding postphagocytic events and intracellular properties of hematopoietic cells.

\section{Acknowledgments}

We thank Dr. J. Brooks, M.D., for his excellent photographic assistance. We gratefully acknowledge Ruth Rowan for her expert assistance in preparing this manuscript for publication.

This work was supported by NIH grants AI-22193 and HL-40387.

\section{References}

1. Unkeless, J. C., E. Scigliano, and V. H. Freedman. 1988. Structure and function of human and murine receptors for IgG. Annu. Rev. Immunol. 6:251281 .

2. Mellman, I. 1988. Relationships between structure and function in the Fc receptor family. Curr. Opin. Immunol. 1:16-25.

3. Kinet, J. P. 1989. Antibody cell interactions: Fc receptors. Cell. 57:351354.

4. Mellman, I., T. Koch, G. Healy, W. Hunziker, V. Lewis, H. Plutner, H. Miettinen, D. Vaux, K. Moore, and S. Stuart. 1988. Structure and function of Fc receptors on macrophages and lymphocytes. J. Cell. Sci. Suppl. 9:45-65.

5. Unkeless, J. C. 1989. Function and heterogeneity of human Fc receptors for immunoglobulin G. J. Clin. Invest. 83:355-361.

6. Ravetch, J. V., and C. L. Anderson. 1989 . Fc r $_{\gamma}$ receptor family: proteins, transcripts and genes. In Receptors and the Action of Antibodies. H. Metzger, editor. American Society for Microbiology, Washington, DC 221-235.

7. Anderson, C. L., and R. J. Looney. 1986. Human leucocyte IgG Fc receptors. Immunol. Today. 7:264-266.

8. Gergely, J., and G. Sarmay. 1989. IgG Fc receptors: ligand binding and lysis induction. Immunol. Lett. 20:1-4.

9. Schreiber, A. D., F. Gomez, A. I. Levinson, M. D. Rossman. 1989. The Fc receptor on human macrophages. Transfusion Medicine Review. 3:281-293.

10. Tabilio, A., J. P. Rosa, U. Testa, N. Kieffer, A. T. Nurden, M. C. Del Canizo, J. Breton-Gorius, and W. Vainchenker. 1984. Expression of membrane glycoproteins and alpha-granule proteins by a human erythroleukemia cell line (HEL). EMBO (Eur. Mol. Biol. Organ.) J. 3:453-459.

11. Rappaport, E. F., D. L. Cassel, S. E. McKenzie, R. P. Meister, S. Surrey, A. D. Schreiber, and E. Schwartz. 1990. An Fc RIIA transcript encoding a soluble receptor can arise by alternative splicing of the transmembrane exon. Blood. 76:191a.

12. Rappaport, E. F., D. L. Cassel, S. E. McKenzie, S. Sullen, E. Schwartz, and A. D. Schreiber. 1991. Expression of $\mathrm{Fc}_{\boldsymbol{\gamma}} \mathrm{RII}$ in hematopoietic cells: analysis of 
transcripts encoding the soluble and membrane associated molecular forms. Clin. Res. 39:151A.

13. Rosenfeld, S. I., R. J. Looney, J. P. Leddy, D. C. Phipps, G. N. Abraham, and C. L. Anderson. 1985. Human platelet Fc receptor for immunoglobulin G. Identification as a $\mathbf{4 0 , 0 0 0}$ molecular-weight membrane protein shared by monocytes. J. Clin. Invest. 76:2317-2322.

14. Ezekowitz, R. A. B., K. Sastry, P. Bailly, and A. Warner. 1990. Molecular characterization of macrophage mannose receptor: demonstration of multiple carbohydrate recognition-like domains and phagocytosis of yeasts in COS-1 cells. J. Exp. Med. 172:1785-1794.

15. Allen, J. M., and B. Seed. 1989. Isolation and expression of functional high affinity Fc receptor complementary DNAs. Science (Wash. DC). 243:378 381 .

16. Hibbs, M. L., L. Bonadonna, B. M. Scott, I. F. McKenzie, and P. M. Hogarth. 1988. Molecular cloning of a human immunoglobulin G Fc receptor. Proc. Natl. Acad. Sci. USA. 85:2240-2244.

17. Fanger, M. W., L. Shen, R. F. Graziano, and P. M. Guyre. 1989. Cytotoxicity mediated by human Fc receptors for IgG. Immunol. Today. 10:92-99.

18. Comber, P. G., M. D. Rossman, E. F. Rappaport, P. Chien, P. M. Hogarth, and A. D. Schreiber. 1989. Modulation of human mononuclear phagocyte F $c_{\gamma}$ RII mRNA and protein. Cell. Immunol. 124:292-307.

19. Schreiber, A. D., J. Parsons, P. McDermott, and R. A. Cooper. 1975 Effect of corticosteroids on the human monocyte IgG and complement receptors. J. Clin. Invest. 56:1189-1197.

20. Papayannopoulou, T., B. Nakamoto, T. Yokochi, A. Chait, and R. Kannagi. 1983. Human erythroleukemia cell line (HEL) undergoes a drastic macrophage-like shift with TPA. Blood. 62:832-845.
21. Anderson, C. L., L. Shen, D. M. Eicher, M. D. Wewers, and J. K. Gill. 1990. Phagocytosis mediated by three distinct $\mathrm{Fc}_{\gamma}$ receptor classes on human leukocytes. J. Exp. Med. 171:1333-1345.

22. Munn, D. H., M. McBride, and N. K. Cheung. 1991. Role of low affinity Fc receptor in antibody-dependent tumor cell phagocytosis by human monocytederived macrophages. Cancer Res. 51:1117-1123.

23. Kurlander, R. J., D. M. Ellison, and J. Hall. 1984. The blockade of Fc receptor-mediated clearance of immune complexes in vivo by a monoclonal antibody (2.4G2) directed against Fc receptors on murine lymphocytes. $J$. Immunol. 133:855-862.

24. Joiner, K. A., S. A. Fuhrman, H. M. Miettinen, L. H. Kasper, and I. Mellman. 1990. Toxoplasma gondii: fusion competence of parasitophorous vacuoles in Fc receptor-transfected fibroblasts. Science (Wash. DC). 249:641-646.

25. Ceuppens, J. L., M. L. Baroja, F. Van Vaeck, and C. L. Anderson. 1988. Defect in the membrane expression of high affinity $72-\mathrm{kD} \mathrm{Fc}_{\gamma}$ receptors on phagocytic cells in four healthy subjects. J. Clin. Invest. 82:571-578.

26. Passlick, B., D. Flieger, and H. W. Ziegler-Heitbrock. 1989. Identification and characterization of a novel monocyte subpopulation in human peripheral blood. Blood. 74:2527-2534.

27. Schreiber, A. D., P. Chien, A. Tomaski, and D. B. Cines. 1987. Effect of danazol in immune thrombocytopenic purpura. N. Engl. J. Med. 316:503-508.

28. Clarkson, S. B., J. B. Bussel, R. P. Kimberly, J. E. Valinsky, R. L. Nachman, and J. C. Unkeless. 1986. Treatment of refractory immune thrombocytopenic purpura with an anti-Fc ${ }_{\gamma}$ receptor antibody. $N$. Engl. J. Med. 314:12361239. 